\title{
Which birds participate in mass concentrations of Bramblings Fringilla montifringilla?-Ring recoveries, biometry, age and sex composition
}

\author{
Lukas Jenni ${ }^{1}$ (D) \\ Received: 7 April 2021 / Revised: 7 July 2021 / Accepted: 12 July 2021 / Published online: 30 July 2021 \\ (c) The Author(s) 2021
}

\begin{abstract}
The Brambling Fringilla montifringilla combines several special features of migration and wintering: differential migration according to age and sex groups, large differences in winter densities as a response to food availability, and flocking behaviour as a response to local mass fructification of the beech Fagus sp. resulting in roosts of several million birds. This study examines (a) whether Bramblings participating in mass concentrations originate from different, or additional, breeding grounds compared with birds present in normal winters, and (b) how differential migration according to age and sex groups combines with irruptive migration and with congregations in mass roosts, i.e., whether the benefits from mass concentrations differ between age and sex groups. Wing biometry (wing length, lengths of outer primaries, and wing pointedness) did not vary geographically, as shown by museum skins, and was therefore not helpful to reveal differences in origin between birds of mass concentrations and normal winters. The extent of the post-juvenile moult was smaller in mass concentration birds and suggests that slightly later-born juveniles, i.e., born further east or north, participate in mass concentrations. Ringing recoveries could not demonstrate a difference in breeding range origin of Bramblings which participate in mass concentrations versus Bramblings in normal winters in Switzerland. However, this may be due to insufficient recoveries of ringed birds. A rough estimate suggests that the number of Bramblings migrating SW on a broad front across Europe could be sufficient to form mass concentrations of up to 10 million birds which are halted by a large area of beech mast. Across Europe, the proportion of juvenile males decreased towards south (i.e., with increasing migration distance) in autumn migrants and wintering birds, while adult females showed the opposite pattern, and adult males and juvenile females were intermediate. Mass concentrations in Switzerland were composed of significantly more adults, especially adult males, and fewer juveniles, particularly juvenile females, while the sex-age composition outside mass concentrations was similar to normal winters. Adults and females likely benefit from wintering further south where snow is less likely to cover food of this ground-feeding finch. On the other hand, the costs of migration are probably substantial in terms of direct costs or indirectly in terms of reaching the breeding grounds, so that juvenile males prefer to winter closer to the breeding area than adults. Feeding in large flocks in beech mast areas incurs the high risk of being cut off from this food by snowfall. Adult males are apparently best adapted to this risk, and hence predominate in mass concentrations.
\end{abstract}

Keywords Differential migration $\cdot$ Mass concentration $\cdot$ Museum skins $\cdot$ Ring recoveries $\cdot$ Biometry $\cdot$ Age and sex composition

Communicated by N. Chernetsov.

Lukas Jenni

lukas.jenni@vogelwarte.ch

1 Swiss Ornithological Institute, Seerose 1, 6204 Sempach, Switzerland 


\section{Zusammenfassung}

Welche Vögel nehmen an Masseneinflügen von Bergfinken Fringilla montifringilla teil? - Ringfunde, Biometrie, Alters- und Geschlechtszusammensetzung.

Bergfinken Fringilla montifringilla zeichnen sich durch einen nach Alter und Geschlecht differentiellen Zug aus. Zudem variiert die Dichte ihres Auftretens in den Winterquartieren als Folge von Schwankungen in der Winternahrung stark. In Gebieten mit einer Buchenvollmast Fagus sp. bilden sich große Schwärme, die sich in Schlafplätzen von mehreren Millionen Vögeln versammeln können. Diese Arbeit untersucht, (a) ob Bergfinken, die an solchen Massenkonzentrationen teilnehmen, aus anderen oder zusätzlichen Brutgebieten stammen als Bergfinken, die in Wintern ohne Masseneinflügen anwesend sind, und (b) wie beim Bergfinken differentieller Zug nach Alter und Geschlecht mit Irruptionen (früher auch Invasionen genannt) und Ansammlungen in großen Schlafplätzen zusammenwirken, d.h. ob der Nutzen von Massenkonzentrationen je nach Alter und Geschlecht unterschiedlich ist. Wie Messungen an Museumsbälgen zeigten, variierte die Biometrie des Flügels (Flügellänge, Länge der äußeren Handschwingen, Flügelspitzigkeit) nicht geografisch und konnte deshalb nicht zur Beantwortung der Frage (a) hinzugezogen werden. Der Umfang der Jugendmauser war bei Vögeln, die an Masseneinflügen teilnahmen, geringer als bei Vögeln aus Normalwintern und legt nahe, dass etwas später (d.h. weiter nördlich oder östlich) geborene Jungvögel an Masseneinflügen beteiligt sind. Ringfunde zeigten keinen Unterschied im Brutgebiet von Bergfinken, die in der Schweiz in Masseneinflugwintern oder in Normalwintern anwesend waren, was aber auf die geringe Anzahl von Ringfunden zurückzuführen sein könnte. Nach Schätzungen reicht die Anzahl Bergfinken, die in breiter Front in südwestlicher Richtung über Europa zieht, aus, um in einer großen Buchenvollmastregion Massenkonzentrationen von bis zu 10 Millionen Vögeln zu bilden. In Europa nahm der Anteil junger Männchen auf dem Herbstzug und im Winterquartier gegen Süden (d.h. mit zunehmender Zugdistanz) ab, während adulte Weibchen das umgekehrte, und adulte Männchen und junge Weibchen ein dazwischenliegendes Muster zeigten. Massenkonzentrationen in der Schweiz enthielten signifikant mehr adulte Bergfinken, insbesondere adulte Männchen, und weniger Jungvögel, insbesondere junge Weibchen, während die Alters- und Geschlechtszusammensetzung außerhalb von Massenkonzentrationen ähnlich war wie in Normalwintern. Adulte und Weibchen ziehen es offenbar vor, weiter südlich zu überwintern, wo das Risiko geringer ist, dass Schnee die Nahrung am Boden zudeckt. Junge Männchen ziehen es vor, näher am Brutgebiet zu überwintern, da sie das Brutgebiet möglichst früh erreichen sollen und so Risiken und Kosten des Zugs vermindern. Massenkonzentrationen in Buchenmastgebieten sind dem großen Risiko ausgesetzt, dass Schnee die überreiche Nahrung zudeckt. Adulte Männchen sind am besten an dieses Risiko angepasst (Dominanz, grosse Fettreserven) und überwiegen in Massenkonzentrationen.

\section{Introduction}

In many bird species, the spatio-temporal migration schedule differs between sex and age groups within a population. Such differential migration may result from sex and age differences in body size, physiology, dominance, experience, and/or breeding roles (Cristol et al. 1999; Ketterson and Nolan 1983; Newton 2008; Payevsky 2020). Depending on intrinsic characteristics and environmental conditions, each group has a different optimum of its migration and wintering grounds.

A further level of complexity to differential migration is added if there is a high yearly variation in food supply, most evident in the huge yearly fluctuations of tree crops in temperate and boreal regions (resource pulses). Hence, the optimum spatio-temporal migration schedule may vary greatly between years.

Furthermore, there is behavioural variation in the way these pulsed food supplies are exploited. Many species congregate in large feeding flocks and even roost together, while others do not or gather in only small groups. The benefits of flocking and communal roosting may also differ between age and sex groups, and hence their spatial distribution within a food rich area. Taking differential migration, yearly variation in food supply and flocking behaviour together, very complex and variable patterns of spatio-temporal migration and wintering may result which can only be unravelled with large-scale and long-term data.

Here, some data are put together which attempt to shed light on the migration and wintering pattern of the Brambling Fringilla montifringilla. This species combines three special features: it is known (a) for its differential migration according to age and sex, (b) for its irruptive migration, and (c) for its facultative mass roosts and large feeding flocks during winter.

Generally, male Bramblings winter further north than females and adults further south than juveniles (Jenni 1982; Payevsky 1998, 2020; Valkama et al. 2014), which in the case of Swedish birds results in juvenile males wintering furthest north, followed by juvenile females, adult males, and adult females (Fransson and Hall-Karlsson 2008). How this general pattern is affected by concentrations in beech mast areas has not been investigated.

The Brambling is listed among the irruptive migrants, but is indeed a special case (Newton 2008). Unlike most irruptive migrant species, all Bramblings leave the breeding 
area, hence exhibit a regular, not a facultative and varying, migration. Up to now, there is no indication that regional fluctuations in breeding population size are related to variation in the number of Bramblings at passage or wintering sites, unlike in some tit species. Like all irruptive migrants, Bramblings vary their movements in response to fluctuating food availability. However, for Bramblings, the supply of both summer and winter food varies strongly between years and entails large differences in both local breeding and wintering densities. During the breeding season, Brambling density and productivity is higher in areas and years of autumnal moth Epirrita autumnata outbreaks, and breeding site fidelity is extremely low (Enemar et al. 2004; Hogstad 2000, 2005; Lindström 1987; Lindström et al. 2005; Mikkonen 1983). In winter, the availability of the preferred food, beech seeds, varies strongly between years and areas, and Bramblings congregate in those beech mast areas they encounter first on their autumn migration (Jenni 1987). Because most beech seeds fall to the ground in autumn, the Brambling is the only species which feeds on the ground among the irruptive European finches that depend on tree seeds (Newton 2008), and hence is sensitive to snow cover (Jenni 1987).

Bramblings are known for their exceptionally large roosts of 1-6(-15) million birds which they form in beech mast areas (Jenni 1987; Jenni and Neuschulz 1985). Typically, two or more such large roosts may form in a large beech mast area, so that the number of Bramblings gathering in a beech mast region may number around 10 million birds or more, although all estimates are highly uncertain by a factor of 5 or more (Jenni and Neuschulz 1985). Therefore, the question arises where all these birds come from and whether all age and sex groups participate equally in large roosts.

Because of these special features of Brambling migration and wintering, I prefer to call the large assemblages in beech mast areas mass concentrations, rather than irruptions, a term used mostly for species with a facultative migration linked with variation in population size and food availability in the breeding range.

In Switzerland, Bramblings have been caught in several mass concentrations. Together with data from Bramblings caught abroad and from museum specimens, this allows some light to be shed on the origin and the age and sex composition of birds which participate in mass concentrations.

More specifically, the first question is whether birds participating in mass concentrations originate from different, or additional, breeding grounds compared with Bramblings present in normal winters. The second question is how differential migration according to age and sex groups combines with irruptive migration and with congregations in mass roosts, i.e., whether the participation in mass concentrations differs between age and sex groups. To tackle the first question, I used recoveries of birds ringed or recovered in Switzerland and I examined geographical variation in wing biometry and in the extent of the post-juvenile moult. To examine the second question, I used several data sets on age and sex composition of Bramblings caught during autumn migration and winter.

\section{Materials and methods}

\section{Recoveries of ringed birds}

Many more recoveries of ringed Bramblings have accumulated in the database of the Swiss Ornithological Institute since the last analysis 40 years ago (Jenni 1982). Therefore, it was worth re-examining the origin of birds involved in Swiss mass concentrations versus birds not involved in mass concentrations. I used the 45 birds ringed north of $55^{\circ}$ $\mathrm{N}$ (the approximate lower latitude of the breeding range) and recovered in Switzerland, or ringed in Switzerland and recovered north of $55^{\circ} \mathrm{N}$. Of these, 23 were encountered in the breeding area between May and August, and 22 during autumn migration (September, October).

Furthermore, I re-examined the finding that birds encountered during years of mass concentrations in Switzerland visit more dispersed sites during another winter than birds not encountered in years of mass concentrations (Jenni 1982) by applying more strict criteria than previously, namely only encounters between 15 November and the end of March when birds are in their wintering area $(n=85)$.

Finally, I checked whether birds ringed during the autumn migration in Switzerland visited different areas during the subsequent winter in years of mass concentrations than in normal years $(n=51)$.

\section{Wing biometry and extent of post-juvenile moult}

\section{Museum specimens}

Because Bramblings caught in mass concentrations had slightly shorter wings than during autumn migration (see below), I investigated whether there is a clinal variation in wing morphology across longitude in the breeding range which could reveal the origin of birds taking part in mass concentrations. I therefore concentrated on birds collected during the breeding season. However, because specimens from the Far East were rare in the collections I examined, I also measured skins from the non-breeding season. I measured wing length and the length of the outer primaries 9, 8, 7, and 6 (P9-P6) (following Jenni and Winkler 1989) of 579 skins of the Natural History Museum, Tring UK, Natural History Museum of Denmark, Copenhagen, The Arctic University Museum of Norway, Troms $\varnothing$, Natural History Museum, University of Oslo, Zoologisches Forschungsmuseum Alexander Koenig, Bonn, Swedish Museum of Natural 
History, Stockholm, Finnish Museum of Natural History, Helsinki (see Acknowledgements).

I did not measure birds in primary moult which occurs in August. The first birds with fresh, full-grown primaries (adults after moult or juveniles) occurred in August, while all birds in July had worn primaries. Therefore, I denoted August as the first, and July as the last, month of primary wear (termed feather-month).

Wing shape was captured in two indices: (a) pointedness is the sum of the differences between the usually longest primary (P7) and the other three primaries forming the wingtip divided by the length of $\mathrm{P} 7$, i.e., $[(\mathrm{P} 7-\mathrm{P} 6)+(\mathrm{P} 7$ $-\mathrm{P} 8)+(\mathrm{P} 7-\mathrm{P} 9)] / \mathrm{P} 7$; (b) the difference between the usually longest primary $\mathrm{P} 7$ and the usually second longest primary P8 which is the longest in a minority of birds.

Birds during the first year of life, i.e., EURING Code 3 and 5 , are called juveniles.

\section{Live birds}

Because the differences in wing biometry between different samples of Bramblings were small, I only used measurements which I collected myself or which were collected by colleagues who measured the same way as I did (mostly ascertained through calibrations). Because the variation between ringers is less for P8 than for wing length (Jenni and Winkler 1989), I used P8 data from more ringers than for wing length. For sites in Switzerland, see Fig. 1. Again, birds during the first year of life are called juveniles.

The length of P8 was measured according to Jenni and Winkler (1989) on Col de Bretolet (1977-2020, $n=5993$, by 19 ringers), at a small roost in Basel (21-30 January $1981, n=123$, by LJ), at a feeding site during a mass concentration year at Montagny-les-Monts (6 and 12 January $1985, n=181$, by T. Blanc), and at three large roosts in Switzerland: Röserental (24 and 26 January 1978, $n=74$ dead birds, by LJ); Neuenkirch (23 December-9 February 1982/83, $n=551$, by LJ); Frick (26-29 December 1992 and 2 January 1993, $n=548$, calculated from Kestenholz and Schaffner 1993).

Wing length (maximum length) was measured on Col de Bretolet (1977, 1980-1983, $n=198$, by LJ), at a small roost in Basel (21-30 January 1981, $n=123$, by LJ), and at three large roosts in Switzerland: Röserental (24 and 26 January $1978, n=237$ dead birds, by E. Sutter); Kernwald (8 December-20 January $1977 / 78, n=767$, by R. Winkler); Neuenkirch (23 December-9 February 1982/83, $n=552$, by LJ).

Measures of P9-P6 and P10 were available from Col de Bretolet $(n=150)$, and the two large roosts Röserental $(n=73)$ and Neuenkirch $(n=551)$, from which the two indices of wing shape were calculated as for museum skins.

\section{Extent of post-juvenile greater covert moult}

In many passerines, the extent of the partial post-juvenile moult has been shown to be correlated with hatching date, hence might give an indication of natal origin when breeding times vary geographically (Jenni and Winkler 2020a). In Bramblings, juveniles moult only part of their plumage in late summer including on average 7.5 (range 0-10) of their 10 greater coverts, while adults perform a complete moult (Jenni and Winkler 2020a). The number of non-moulted greater coverts in juveniles was recorded on Col de Bretolet (35 years between 1980 and 2019, $n=3812$ ) and in the samples from Röserental $(n=83)$, Neuenkirch $(n=238)$, and
Fig. 1 Map of Switzerland with the sites mentioned in the text. Open symbols: data on age and sex composition. Filled symbols: data on biometry and on age and sex composition

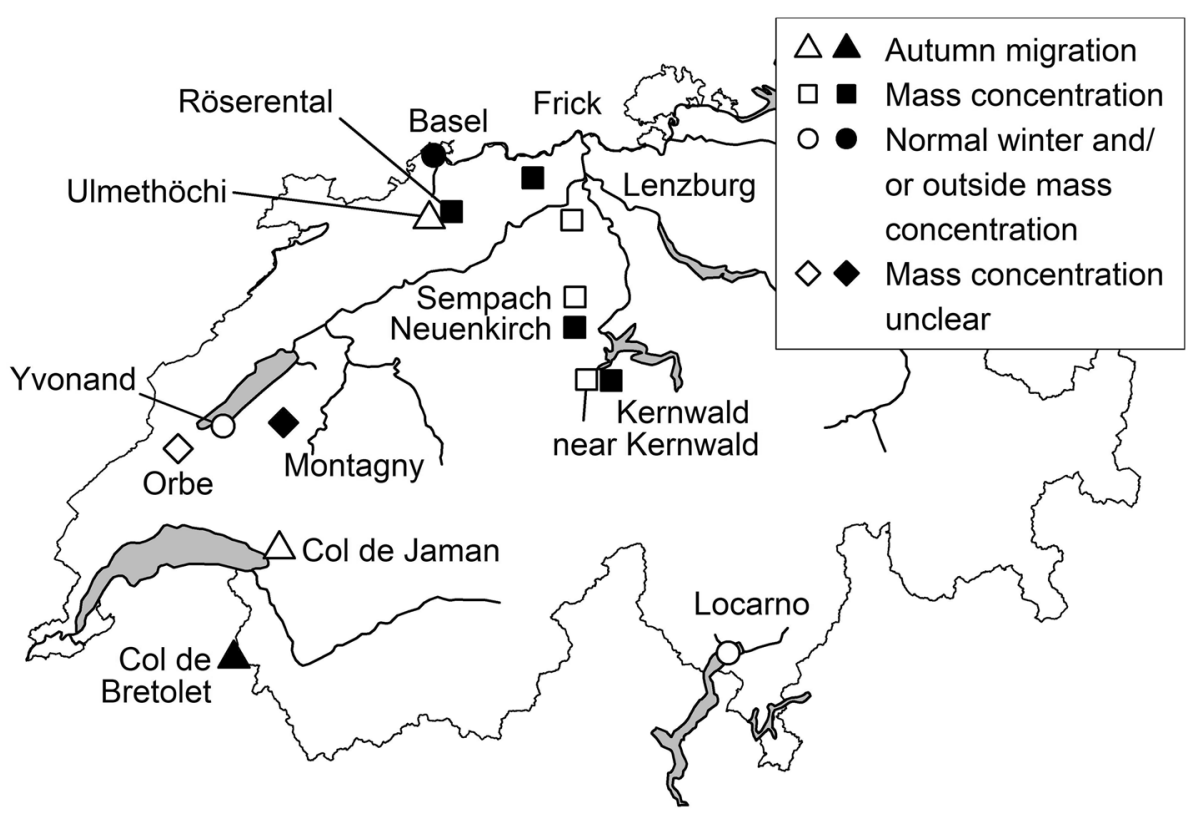


Basel $(n=98)$, as well as in the juvenile museum specimens $(n=343)$.

\section{Age and sex composition}

The sex composition may vary between flocks and within a roost (Jenni 1993, M. Antoniazza in litt.). Moreover, the age may be difficult to determine with progressing season, especially in juveniles with all greater coverts moulted (about 3.7\%; Jenni and Winkler 2020a). Therefore, only data from several days and usually at least 100 birds from experienced ringers ( $>95 \%$ of individuals aged) were used. For sites, see Fig. 1.

Age and sex composition during autumn migration in Switzerland (October, a few birds in late September and early November) was obtained from two Alpine passes and one pass in the Jura mountains where Bramblings in active migration were caught by various ringers: Col de Bretolet (1977, 1980-1983, 1988-2020, $n=8753$, by 26 ringers), Col de Jaman (1994-2019, $n=3445$, by 22 experienced ringers), and Ulmethöchi (1987-2020, $n=1689$, by 13 experienced ringers).

Birds caught during normal winters were from a feeding place and a small roost (in 2015/16) near Locarno, southern Switzerland (P. Teichert, $n=597$ ), and a feeding place at Yvonand, western Switzerland (M. Antoniazza, $n=428$ ) during the seven winters $(2007,2008,2010,2012,2015$, 2017, 2019) without a mass concentrations in Switzerland or nearby, and from a roost of about 10,000 Bramblings and Common Chaffinches Fringilla coelebs in a city park in Basel (21-30 January 1981, LJ, $n=123$ ).

During six winters with a mass concentration in Switzerland, some Bramblings were caught at the feeding places near Locarno (P. Teichert, $n=77$ ) and at Yvonand (M. Antoniazza, $n=57$ ), clearly outside the feeding range of the mass concentrations (winters 2009, 2001, 2013, 2014, 2018, 2020).

During the mass concentration 1977/78, snow covered the beech seeds on the ground in mid-February and most Bramblings abandoned the two main roosts Kernwald and Röserental (Jenni and Neuschulz 1985). From 11 to 18 February, Bramblings were caught in large numbers near Orbe, western Switzerland, where they fed on fields with hardly any snow cover (M. Antoniazza, $n=1633$ ). During the winter 1984/85, large numbers also occurred in western Switzerland, but it remained unclear whether they belonged to the feeding range of a large unknown roost or not (Yvonand, 12-19 January 1985, M. Antoniazza and C. Roulier, $n=256$; Montagny, 6-13 January 1985, T. Blanc, $n=820$ ). These three datasets were classified as "mass concentration unclear".
Age and sex composition was obtained from 5 large roosts and their feeding areas (radius 30-40 km; Jenni and Neuschulz 1985): During the winter 1977/78, Bramblings were caught at the Kernwald roost (8 December-20 January, R. Winkler, $n=851$ ), near this roost (R. Calvetti, $n=348$ ) and in its foraging area near Sempach (16-20 January, R. Lévêque, $n=182$ ), as well as at the Röserental roost (birds casualties at a power line during fog on 24 and 26 January when flying into the roost in the evening; E. Sutter, Natural History Museum Basel, $n=236$ ) and in its foraging area (Lenzburg, 8-28 February, M. Hüni, $n=530$ ) (see Jenni and Neuschulz 1985 for details); during the winter 1982/83 in the Neuenkirch roost in high nets (25 January-9 February, LJ, $n=242$, see Jenni 1993 for details); at a roost near Frick which was occupied during the winter 1987/88 (6-18 February, M. Hüni, $n=296$ ) and during the winter 1992/93 (26 December-2 January, calculated from Kestenholz and Schaffner 1993, $n=663$ ).

Because these samples were collected over a restricted period of the winter, or were too small, I could not analyse whether the proportion of juveniles declined over winter which could indicate a higher winter mortality of juveniles than adults. However, there was no such indication in a large roost in northern Spain which was followed over the entire winter (Arizaga et al. 2012).

Data on age and sex composition during autumn migration abroad (mainly October, a few birds from the end of September and the first half of November) were kindly provided from Ottenby, Öland, Sweden (1972-2020 without 1984 when most not aged, $n=1651$ ), Falsterbo, South Sweden (1980-2020, $n=1987)$, near Lund, South Sweden (1984-1987, ̊̊. Lindström, $n=389$ ), Rybachy, Courish Spit, Russia (2000-2017, $n=6143$ ), Greifswalder Oie in the Baltic Sea, Northeast Germany (1994-2020, $n=1042)$, and at Sasnovy Bor, Belarus $\left(56.0^{\circ} \mathrm{N} / 28.6^{\circ} \mathrm{E}, 2016-2020\right.$, D. Kitel, $n=622$ ).

Data on age and sex composition during winters without mass concentrations were taken from the literature: Sörmland, South Sweden (winter 1976/77, $n=297$, Widemo 1977), Strasbourg, France (winter $1955 / 56, n=214$, Schierer 1957), Catalonia, northeastern Spain (winter 1993/94, $n=113$, Robson 1996), and Norfolk UK (winters 1994/95-2001/02 taken together, $n=2330$, Browne and Mead 2003). Data from mass concentrations were available from a roost at Västersjön, South Sweden (January-February 1993, birds found dead or exhausted, $n=127$, Kjellén and Lindström 1993; bird caught at the edge of the roost probably showed a biased sex and age composition and were omitted, see Jenni 1993), a roost at Barazar, Bizkaia, northern Spain (29 November-6 February 2010/11, $n=1603$, Arizaga et al. 2012), and a roost at Lödersdorf, Steiermark, Austria (17 January-23 February 2009, $n=1229$, Khil et al. 2011). 


\section{Results}

\section{Recoveries of ringed birds}

Birds encountered in Switzerland during autumn or winter which had been ringed or found in the breeding area during the breeding season ( $n=23$ : 16 in May, 1 in July, 6 in August) were found at localities ranging from Norway to West Siberia $\left(10^{\circ}-66^{\circ} \mathrm{E}\right)$. There was no obvious difference in breeding origin between years with or without mass concentrations in Switzerland (Electronic supplementary material Fig. S1). However, birds in May could still have been on migration (Cramp and Perrins 1994; Glutz von Blotzheim and Bauer 1997) and Bramblings are known to change breeding and wintering sites between years. Therefore, only the two recoveries of birds migrating within the same season from the breeding range to winter in Switzerland would be strictly conclusive (one from Norway in May, one from Sweden in August, both found during mass concentration winters in Switzerland). Also, birds ringed during autumn migration in Fennoscandia, Russia, or Latvia $\left(15^{\circ}-33^{\circ} \mathrm{E}\right)$ and found in the following or a later winter in Switzerland indicated no difference in origin between mass concentration and normal winters $(n=22$, not shown).

Birds encountered in Switzerland during a winter with a mass concentration were found at more dispersed locations during a previous or later winter, and slightly further south, than birds from a Swiss normal winter (Table 1; test for difference between the two groups in variance $\left(\mathrm{SD}^{2}\right)$ of longitude and distance: $F_{59,24}=3.69$ and 3.69, respectively, $p<0.001$, Sokal and Rohlf 1995; difference in mean latitude: ANOVA $F_{1,83}=4.7, p=0.03$ ). The extremes of mass concentration birds were winter sites in Portugal and Ireland in the west and in Kosovo, Romania, and Georgia in the east (Fig. S2). In contrast, birds wintering in Switzerland during a normal year were found between SW-France (Lot-et-Garonne) and Slovakia, and they showed a smaller variance in longitude and distance (Table 1, Fig. S2).

Birds ringed in Switzerland during autumn migration (47 in October, 4 in early November) and recovered during the subsequent winter showed a significantly more northerly wintering location when recovered in a winter with a mass concentration in Switzerland than when recovered during a normal winter (Table 2, Fig. S3; difference between the two groups in mean latitude: ANOVA, $F_{1,49}=10.2, p=0.002$; distance: $F_{1,49}=5.3, p=0.026$; longitude: $F_{149}=0.16$, $p=0.91$ ). This confirms the earlier finding that Bramblings would winter further south if not held up by a mass fructification of beech (Jenni 1985).

\section{Wing biometry and extent of post-juvenile moult}

\section{Geographical variation in wing biometry}

Wing length and the lengths of the four outermost primaries of the museum specimens did not vary systematically with longitude or latitude (Fig. 2), but differed between the age and sex classes, as expected, and decreased from August (fresh plumage after moult) to July (worn plumage) by $0.6 \mathrm{~mm}$ per month (except for the protected P6; see Electronic supplementary material Table S1 for models and results). Similarly, there was no significant linear variation

Table 1 Bramblings ringed in Switzerland in winter and recovered during a following winter elsewhere (mostly abroad), or ringed during winter abroad and recovered during a following winter in Switzer-

land, subdivided according to the winter in Switzerland with or without a mass concentration (MC)

\begin{tabular}{|c|c|c|c|c|c|c|c|}
\hline & \multicolumn{2}{|c|}{ Latitude $\left({ }^{\circ} \mathrm{N}\right)$} & \multicolumn{2}{|c|}{ Longitude $\left({ }^{\circ} \mathrm{E}\right)$} & \multicolumn{2}{|c|}{ Distance $(\mathrm{km})$} & \multirow[t]{2}{*}{$n$} \\
\hline & Mean \pm SD & Median (Min.-Max.) & Mean \pm SD & Median (Min.-Max.) & Mean \pm SD & Median (Min.-Max.) & \\
\hline Without MC & $48.8 \pm 2.4$ & $49.2(44.3-55.6)$ & $10.2 \pm 3.7$ & $10.1(4.5-17.8)$ & $392 \pm 223$ & $382(24-962)$ & 25 \\
\hline With MC & $47.4 \pm 2.9$ & $46.9(39.8-55.0)$ & $8.9 \pm 7.1$ & $8.3(-8.8-42.4)$ & $471 \pm 429$ & $402(4-2825)$ & 60 \\
\hline
\end{tabular}

Latitude and longitude (with decimals) of the site abroad are given and the distance between the two wintering sites. Winter is from 15 November to end of March

Table 2 Latitude, longitude, and distance of Bramblings ringed during autumn migration in Switzerland and recovered during the subsequent winter in years with and without a mass concentration (MC) in Switzerland

\begin{tabular}{|c|c|c|c|c|c|c|c|}
\hline & \multicolumn{2}{|l|}{ Latitude $\left({ }^{\circ} \mathrm{N}\right)$} & \multicolumn{2}{|c|}{ Longitude $\left({ }^{\circ} \mathrm{E}\right)$} & \multicolumn{2}{|c|}{ Distance (km) } & \multirow[t]{2}{*}{$n$} \\
\hline & Mean \pm SD & Median (Min.-Max.) & Mean \pm SD & Median (Min.-Max.) & Mean \pm SD & Median (Min.-Max.) & \\
\hline Without MC & $43.9 \pm 1.5$ & $44.1(38.1-46.0)$ & $6.7 \pm 3.6$ & $5.7(-3.6-12.7)$ & $374 \pm 207$ & $303(163-1237)$ & 40 \\
\hline With MC & $45.5 \pm 1.3$ & $45.7(43.8-47.5)$ & $6.8 \pm 2.2$ & $6.5(4.1-9.9)$ & $223 \pm 129$ & $175(89-459)$ & 11 \\
\hline
\end{tabular}


Fig. 2 Mean $( \pm S E)$ length of primary $8(\mathrm{P} 8)$, wing pointedness and difference between the length of P7 and P8 for adult (filled symbols) and juvenile (open symbols) males (left) and females (right) according to bands of longitude $\left(10^{\circ}\right.$ bands from $10^{\circ} \mathrm{W}$ to $40^{\circ} \mathrm{E}$, and $30^{\circ}$ bands from $40^{\circ} \mathrm{E}$ to $\left.160^{\circ} \mathrm{E}\right)$. Numbers in the bottom graphs are sample sizes of adults (upper row) and juveniles (lower row)
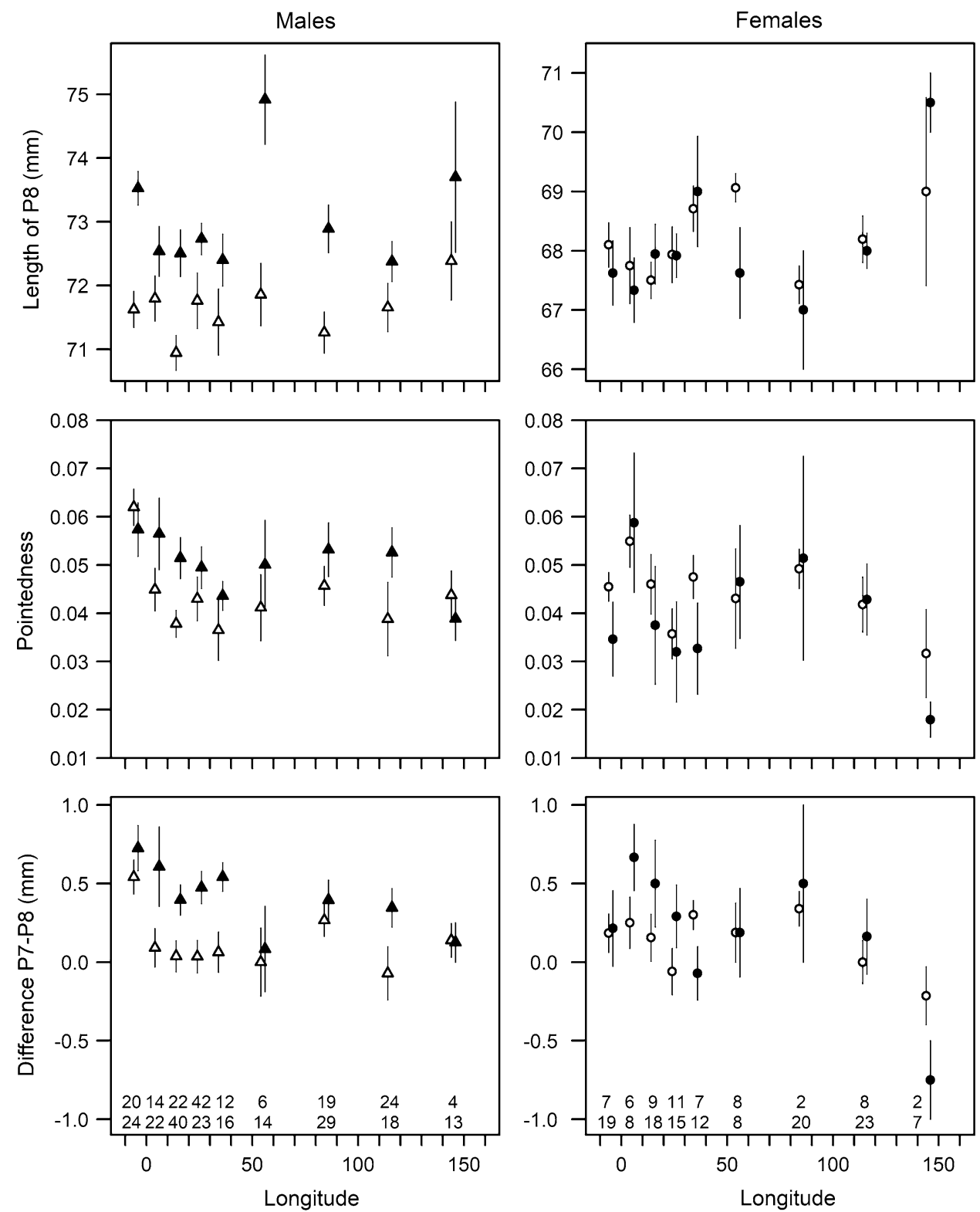

with longitude and latitude when only birds from May to August, or alternatively only from June, were analysed (not shown).

Wing shape changed significantly with longitude, particularly in Europe, and also differed between age and sex classes (see Table S1). More westerly birds had more pointed wings and their longest primary was more often P7 than in eastern birds which had less pointed wings and P8 more often as their longest primary (Fig. 2).

\section{Wing biometry of autumn and winter birds}

On Col de Bretolet, autumn migrants showed no significant change of the length of $\mathrm{P} 8$ with progressing season and no significant difference in $\mathrm{P} 8$ between years with and without a subsequent mass concentration in Switzerland (Table S2).

Although the differences were generally small, P8 and wing length were significantly different between sites for all sex and age classes, except for P8 of young females (6 autumn migration and winter sites for P8, 5 autumn migration and winter sites for wing length: all ANOVAs, $p<0.001$, except for P8 of young females $p>0.3$; Fig. 3 and Fig. S4). P8 of adults and juvenile males was generally about $0.8 \mathrm{~mm}$ longer in autumn migrants than at winter sites, except in adults of the small sample of Basel which were at least as long as on Col de Bretolet (Fig. 3). A similar pattern emerged for wing length which was longest in autumn birds (Col de Bretolet), intermediate in birds from the small roost in Basel, and shortest in the three large winter roosts 
Fig. 3 Mean length of P8 $( \pm \mathrm{SE})$ of birds during autumn migration (Col de Bretolet) at a small roost in Basel, at three large roosts (Röserental, Neuenkirch, Frick), and a feeding site during a mass concentration winter (Montagny) of male (triangles) and female (dots) adults (left) and juveniles (right). Numbers in the graphs are sample sizes of males (upper row) and females (lower row)

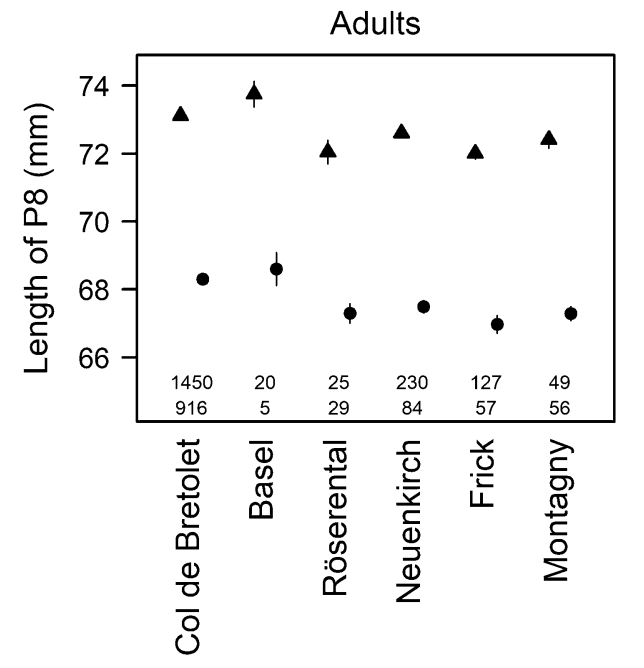

(Röserental, Kernwald, Neuenkirch) (Fig. S4). Wing shape was very similar, and did not differ significantly, between birds caught on Col de Bretolet in autumn and at the two large roosts Röserental and Neuenkirch (not shown). I could not compare wing shape of museum skins with live winter birds, because the measurements of feather lengths differ slightly between fresh birds and museum skins (Jenni and Winkler 1989).

\section{Extent of post-juvenile moult}

During autumn migration at Col de Bretolet, the number of renewed greater coverts in juveniles was affected by season, sex, and whether it was a mass concentration year or not. A Linear Mixed Model with the number of greater coverts as the dependent variable and year as random effect showed that juveniles with progressively fewer renewed greater coverts pass through with progressing season (effect of date: $-0.0144 \pm 0.0025, F=32.4, p<0.001$; Fig. 4); furthermore, males had $0.154( \pm 0.035 \mathrm{SE})$ moulted greater coverts more than females $(F=18.8, p<0.001)$ and juveniles migrating in the 17 years with a subsequent mass concentration in Switzerland had $0.181( \pm 0.089 \mathrm{SE})$ more greater coverts moulted than juveniles migrating in the 21 years without a mass concentration $(F=4.1, p=0.05)$. Individuals migrating across Col de Bretolet were about to leave Switzerland and hence did probably not take part in Swiss mass concentrations.

Juveniles from two mass roosts in Switzerland (Röserental, Neuenkirch) and a small roost in Basel had a less extensive greater covert moult than autumn migrants or resembled late autumn migrants (Fig. 4; the means of the 5 data sets (Col de Bretolet combined) differed significantly for males and females, respectively: ANOVA, $p<0.001$ ).

Museum specimens showed a smaller extent of greater covert moult in the Far East (Fig. 5; Linear Model: effect

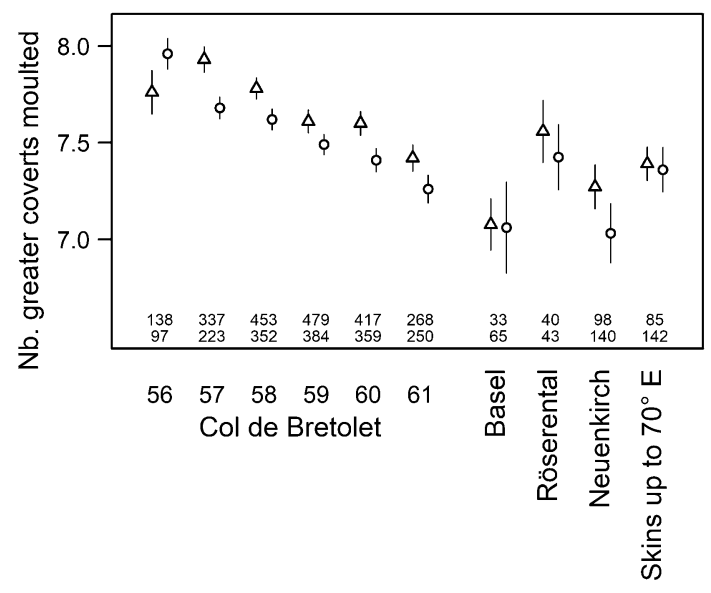

Fig. 4 Mean number of greater coverts moulted $( \pm S E)$ of male (triangles) and female (circles) juvenile Bramblings passing through Switzerland at Col de Bretolet, subdivided into 5-day periods (pentades; pentade 56 starts on 3 October, pentade 61 ends on 1 November); from a small roost in Basel; from two mass roosts in Switzerland (Röserental, Neuenkirch); and museum specimens collected up to $70^{\circ} \mathrm{E}$. Numbers in the graph are sample sizes of females (upper row) and males (lower row)

size of longitude $-0.0038 \pm 0.0016 \mathrm{SE}, F=5.7, p=0.018$; of latitude $-0.0054 \pm 0.0055, p=0.33$; of sex $0.055 \pm 0.122$, $p=0.65$ ). However, up to $70^{\circ} \mathrm{E}$ (the presumed origin of Bramblings wintering in Switzerland), there was no significant decrease in greater covert moult across longitude (Fig. 5; in a similar model effect size of longitude $-0.0020 \pm 0.0039$ SE, $F=0.3, p=0.61$ ). Considering birds collected from May to August up to $70^{\circ} \mathrm{E}$, there was a slight decrease in greater covert moult extent with latitude $(-0.073 \pm 0.038 \mathrm{SE}, p=0.057)$. 


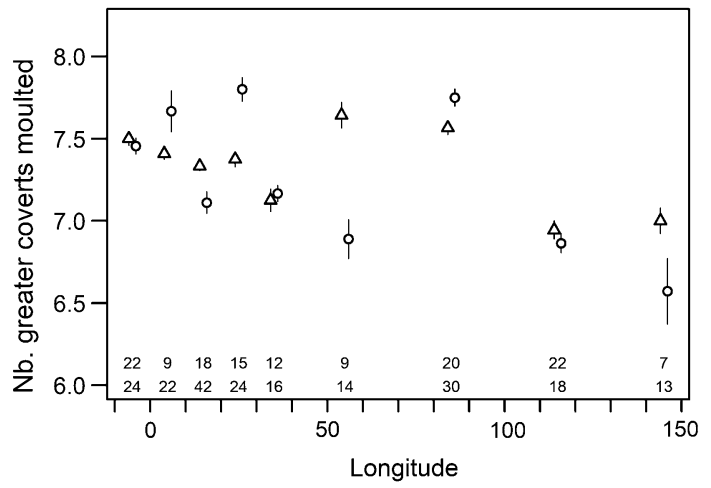

Fig. 5 Mean number of greater coverts moulted $( \pm$ SE) of male (triangles, $n=203$ ) and female (circles, $n=134$ ) juvenile Bramblings collected across Eurasia, divided into bands of longitude $\left(10^{\circ}\right.$ bands from $10^{\circ} \mathrm{W}$ to $40^{\circ} \mathrm{E}$, and $30^{\circ}$ bands from $40^{\circ} \mathrm{E}$ to $160^{\circ} \mathrm{E}$ ). Numbers in the graph are sample sizes of females (upper row) and males (lower row)

\section{Sex and age composition}

During autumn migration on Col de Bretolet, sex and age composition changed with progressing season and whether the subsequent winter was a mass concentration winter (MC) or not (Loglinear Model: highly significant effects of sex $\times$ age, sex $\times$ MC, sex $\times$ pentade and age $\times$ pentade $\times$ MC; 38 years between 1977 and 2020, $n=8753$ ). The proportion of juvenile males and juvenile females decreased through the season, while the proportion of adult males and adult females increased. In years with a subsequent mass concentration in Switzerland, the overall proportion of males was lower than in years without mass concentrations $(53.0 \%$ versus $46.8 \%$ ). The overall proportion of adults was similar between years with and without a subsequent mass concentration in Switzerland, but increased more steeply with season in years with a mass concentration (Fig. 6). At the other two Swiss autumn migration ringing stations Col de
Jaman (1994-2019, 25 years, $n=3445)$ and Ulmethöchi (1987-2020, 34 years, $n=1689$ ), there was a similar change in sex and age composition with progressing season as on Col de Bretolet, but no significant difference between years with and without a subsequent mass concentration in Switzerland.

In winter, the sex and age composition differed significantly between the 16 samples from Switzerland (Loglinear Model: highly significant effects of sex $\times$ sample, age $\times$ sample and sex $\times$ age; similarly when including the three autumn samples). The largest differences pertained to the age classes between samples from mass concentrations and the remaining samples (Fig. 7). Birds caught in large roosts or in their feeding areas comprised over 60\% adults (Röserental two sites, Kernwald three sites, and Neuenkirch one site) or $56 \%$ and $46 \%$ in two roosts in the Fricktal in two different years. In contrast, the percentage of adults was below $40 \%$ among birds caught outside mass concentration areas, in winters without a mass concentration and on autumn migration. For three samples, it remained unclear whether they contained birds from mass concentrations or not, and they showed an intermediate proportion of adults (43-55\%) (Fig. 7).

These differences in adult proportions between mass concentrations and the other samples were mainly caused by the proportion of adult males and juvenile females, while the proportions of adult females and juvenile males differed less. In large roosts and their feeding areas, the proportion of adult males reached 40-53\% (Kernwald, Röserental, Neuenkirch), compared to 9-24\% outside mass concentrations, and was as low as $11-17 \%$ for juvenile females in large roosts, compared to $30-51 \%$ outside mass concentrations (Fig. 7). As a consequence, the proportion of males did not vary much between mass concentrations and outside mass concentrations, although males predominated in the large roosts Kernwald and Neuenkirch with 70-79\% (Fig. 7). This is confirmed by samples whose birds have only been sexed, but not aged, i.e., the large roosts in the winter 1950/51 near
Fig. 6 Percentages of the four age and sex classes over the autumn migration season on Col de Bretolet (in pentades, pentade 56 starts on 3 October, pentade 61 ends on 1 November) for (left) years without and (right) with a mass concentration (MC) in Switzerland in the subsequent winter

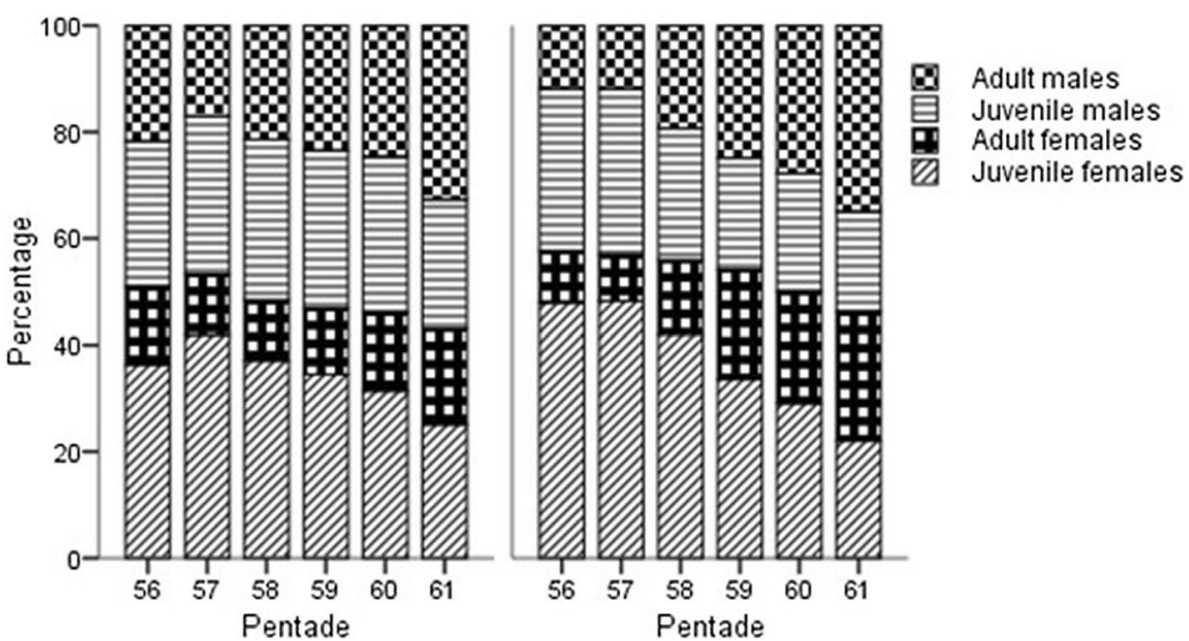


Fig. 7 Proportions (with 95\% confidence intervals) of adult males, juvenile males, adult females, juvenile females, adults and males of 19 samples from Switzerland. For sample sizes, see Materials and methods. The samples are arranged into five groups: autumn migration (mainly October); normal winters, i.e., winters without a mass concentration (MC) in Switzerland (shaded grey), birds caught outside the area of mass concentrations in winters with an MC somewhere else in Switzerland; birds caught in winters with an MC in Switzerland, but unclear whether the birds belonged to an MC or not (shaded grey); birds caught at five different large roosts $(\mathrm{R})$ or in the feeding area (FA) of a large roost
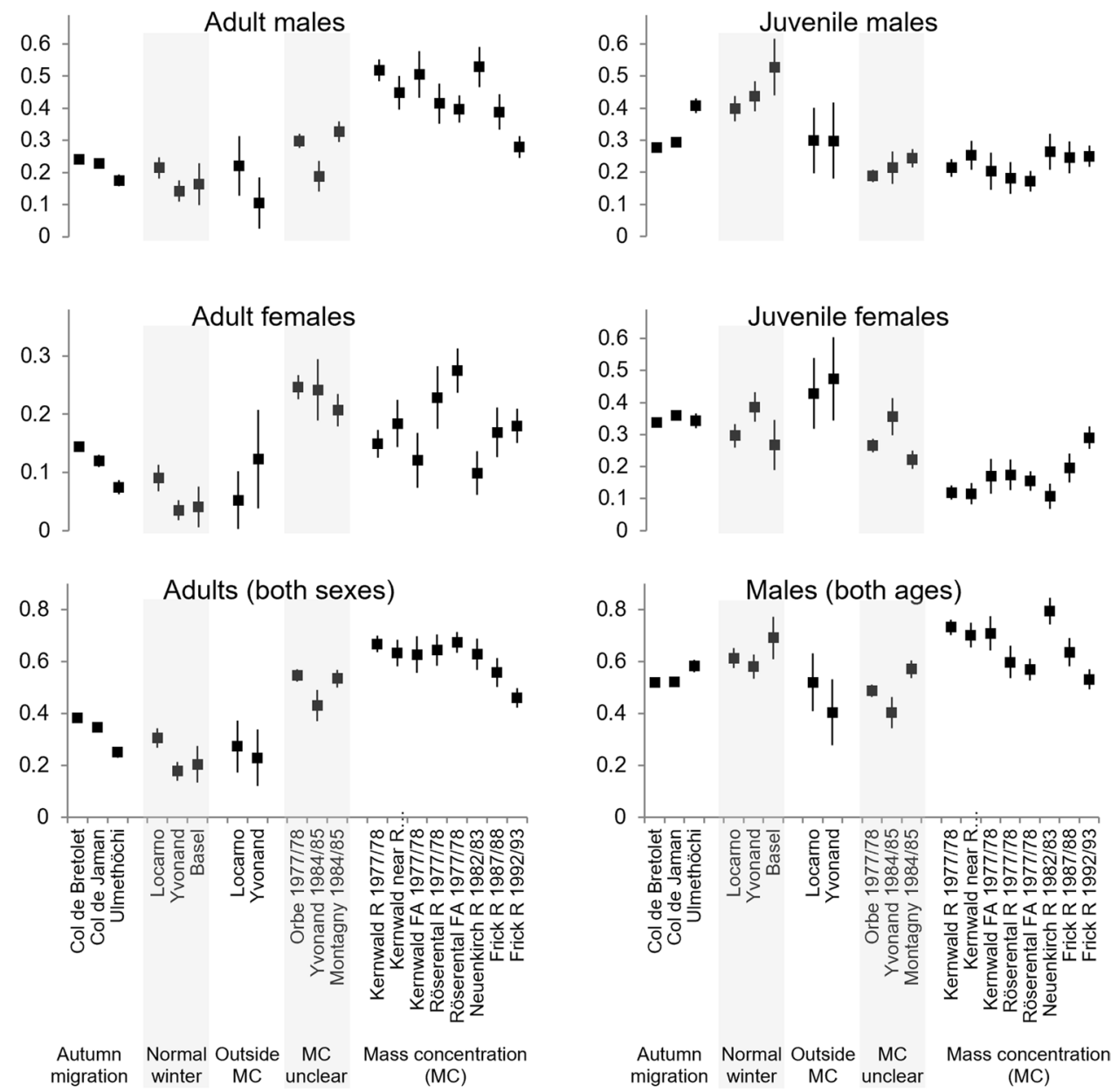

Autumn Normal Outside MC
migration winter MC unclear migration winter MC unclear (MC)

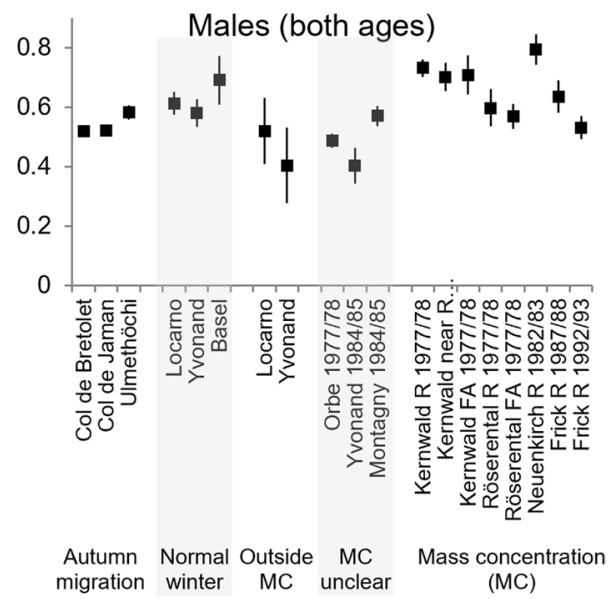

Thun (61\% males, $n=304$; Mühlethaler 1952) and 1965/66 at Würenlos (64\%, $n=640$, Swiss ringing scheme).

Interestingly, the age and sex composition of the two large roosts Kernwald and Röserental which were occupied simultaneously, differed: while the proportion of adults was similar, there were more adult males (50\%), and less adult females (15\%), present in Kernwald than in Röserental (40\% and $26 \%$, respectively).

The relationship of the age and sex composition with latitude across Europe was examined by including data from abroad (see Materials and methods). During autumn migration, the proportion of adults of both sexes increased towards south which resulted in a more or less constant proportion of males (both ages taken together) across latitude (Fig. 8).

In winters without mass concentrations, generally more males wintered further north than females (Fig. 8). This gradient was mainly due to juvenile males, while adult males were more evenly distributed across latitude. In females, the gradient of increasing proportions wintering further south was mainly due to the adult females (Fig. 8). This resulted in adults wintering on average further south than juveniles (Fig. 8).
The finding from Switzerland that adults congregate more in mass concentrations than juveniles is corroborated by the data from abroad (Fig. 8), i.e., from roosts in N-Spain (Arizaga et al. 2012) and Austria (Khil et al. 2011), while the sex and age composition of the relatively small sample $(n=127)$ from a roost in S-Sweden matched more those of normal winters, but may not be representative, because it consisted of birds found dead and exhausted in the roost (Kjellén and Lindström 1993).

\section{Discussion}

This study suggests that there is hardly any difference in breeding origin of Bramblings migrating through Switzerland, wintering in Switzerland during winters without mass concentrations and winters with mass concentrations as a result of beech mast. This study confirms a differential migration of the Brambling with males generally wintering further north in Europe than females, while adults winter further south within each sex class. Mass concentrations consist of a higher proportion of adults than present outside 
Adult males

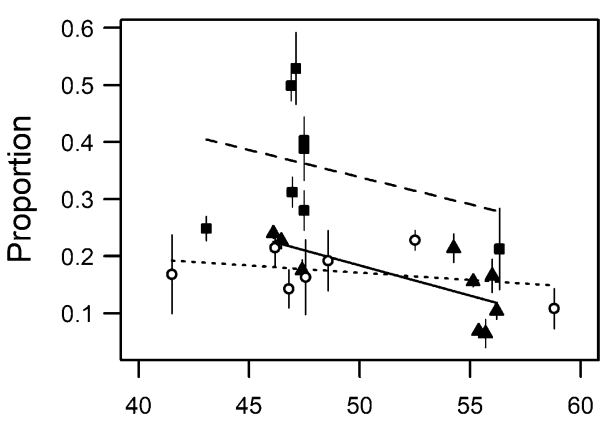

Adult females

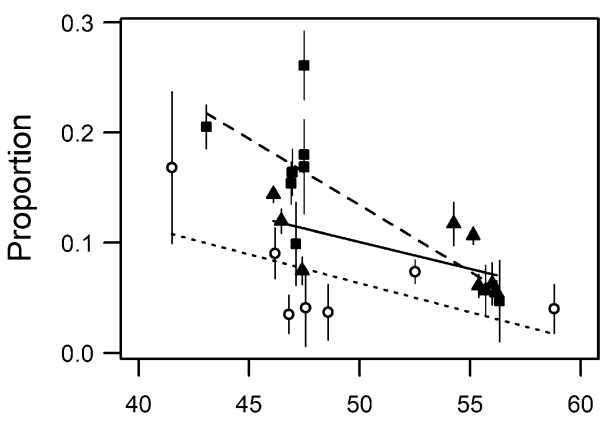

Adults (both sexes)

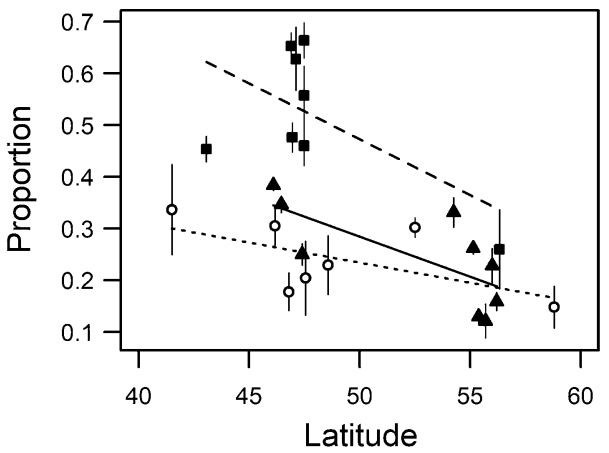

Fig. 8 Proportions (with 95\% confidence intervals) of adult males, juvenile males, adult females, juvenile females, and adults and males versus latitude for three groups of samples from Europe: birds during autumn migration ( $n=9$, filled triangles, continuous regression line); normal winters $(n=7$, circles, dotted regression line), i.e., winters without a mass concentration (MC) in the respective country; birds caught at large roosts or in their feeding area $(n=8$, filled squares, dashed regression line). The samples from Switzerland from Fig. 7 are between $46^{\circ}$ and $48^{\circ} \mathrm{N}$ (the three Kernwald samples and the two Röserental samples combined, respectively). For sample sizes and

mass concentrations and during winters without mass concentrations.

\section{Origin of Bramblings participating in mass concentrations: wing biometry}

The first aim of this study was to find out, using geographical variation in wing biometry and recoveries of ringed birds,
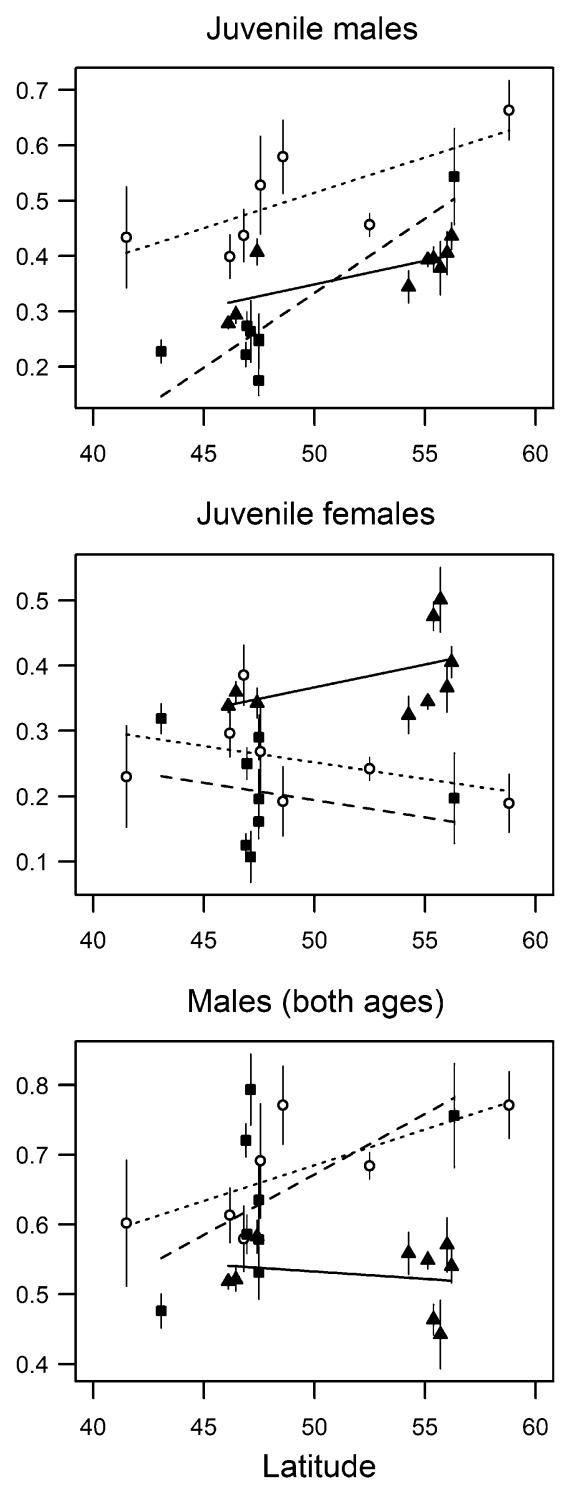

data from abroad, see Materials and methods. General linear models for each sex and age class separately with the respective proportion as the dependent variable revealed significant differences in intercept among the three groups (autumn migration, normal, and mass concentration winters; $p<0.004$ ) for all sexes and ages, and a significant relationship with latitude $(p<0.003)$ for juvenile males, adult females and adults, while the relationship with latitude was marginally significant in adult males $(p=0.07)$ and males $(p=0.06)$, and non-significant in juvenile females $(p=0.84)$ (the interaction term group $\times$ latitude was never significant)

whether birds which participate in mass concentrations originate from different, or additional, breeding grounds compared with Bramblings present in normal winters.

Wing length and feather lengths were very similar across the Palaearctic, and hence cannot be used to reveal the origin of wintering birds (see also Hogstad 1985 for the absence of a latitudinal cline in Norway and Sweden). This more or less invariable wing biometry may be due to the mixing 
caused by the regular and large-scale breeding dispersal of the Brambling (Lindström 1987), but is still surprising given the large distribution area across the whole of Eurasia and some variation in coloration (birds in the far east are more brightly coloured and formerly separated as subcuneolata; Cramp and Perrins 1994). Not surprisingly, wing biometry within the autumn migration season in Switzerland (Col de Bretolet) did also not vary.

Bramblings wintering in Switzerland, especially those in mass concentrations, had slightly shorter wings and P8 than autumn migrants, while wing shape was similar. Data from the literature confirm that summer/autumn birds have relatively long wings (Ålbu 1983, data from Falsterbo Bird Obyservatory), while winter birds have shorter wings (Arizaga et al. 2012; Robson 1996; Widemo 1977; Electronic supplementary material Table S3). Three explanations could account for the observed difference in wing length between autumn and winter birds: (a) longer winged individuals could migrate over longer distances and cross the Alps and reach southern Europe, but central Norwegian birds (Ålbu 1983) are not expected a priori to perform particularly long migrations. (b) Wing length has been observed to vary between years in the breeding area (Hogstad 1985; Lindström 1987), but this was attributed to differences in the proportion of first-year birds and adults, although Lindström (1987) found significant yearly differences in adult females, but not in the other age-sex groups. (c) Most likely, however, the difference between autumn and winter birds is due to feather wear. Abrasion of wing length is in the order of $0.2-0.5 \%$ per month (Jenni and Winkler 2020b; hence in Bramblings nearly $0.2-0.5 \mathrm{~mm}$ ) and was estimated at $0.6 \mathrm{~mm}$ per month from the museum specimens. Abrasion can therefore easily explain the $0.8 \mathrm{~mm}$ shorter length of the wing or P8 of winter compared with autumn birds.

As has been shown in several passerine species in the field and in experiments, juveniles with a more extensive post-juvenile moult started moult at an earlier date, hence are of earlier broods (Jenni and Winkler 2020a). The extent of the post-juvenile moult of birds migrating through Switzerland (Col de Bretolet) was more extensive in early than late migrants and in years of a subsequent mass concentration in Switzerland, while birds taking part in Swiss mass concentrations had a less extensive post-juvenile moult. This indicates that later-born individuals migrate through Switzerland later than early born birds (as in many other species; Jenni and Winkler 2020a) and that on average slightly laterborn individuals more commonly take part in mass concentrations. The museum specimens indicated no significant change of the post-juvenile moult extent with longitude up to $70^{\circ} \mathrm{E}$, but a trend towards a less extensive post-juvenile moult with latitude. However, this finding may be flawed by the fact that the site of post-juvenile moult (probably near the site of birth) may not be close to the site of first breeding where the juveniles (in their second-calendar year) were collected, because Bramblings readily change breeding sites.

As shown in 21 Palaearctic passerine species, the extent of the partial post-juvenile moult was smaller east of the Ural mountains than in the western Palaearctic, probably because of a shorter vegetation season and hence less time available for moult in the east (Kiat et al. 2021). Therefore, juvenile Bramblings which take part in mass concentrations in Switzerland are probably born later and hence possibly of more eastern and/or northern origin than autumn migrants.

\section{Origin of Bramblings participating in mass concentrations: recoveries}

In autumn, Bramblings migrate in a south-westerly direction (except birds from Norway which often show southern directions; Bakken et al. 2006; Zink and Bairlein 1995), so that birds from more eastern breeding areas migrate along a more easterly route and reach more eastern wintering sites than birds from more westerly origin (see the recoveries within the same season in Zink and Bairlein 1995; see also Bakken et al. 2006; Bønløkke et al. 2006; Fransson and HallKarlsson 2008; Valkama et al. 2014; Wernham et al. 2002). Because of a lack of recoveries, the question remains how far this pattern of parallel SW migration directions extends to the east into the Siberian breeding range.

Considering only same-season recoveries during autumn and winter (i.e., ringed in summer or autumn, recovered in the same autumn or subsequent winter), the spread of migration directions of Bramblings does not seem larger than in other species (cf. same-season recoveries of Brambling and Common Chaffinch in Zink and Bairlein 1995, see also Bairlein et al. 2014; Bønløkke et al. 2006). For example, the spread of directions of autumn migrants caught at the Courish Spit and recovered between the following December and February is $34^{\circ}$ for the Chaffinch and $40^{\circ}$ for the Brambling (not considering one outlier which would increase the spread to $67^{\circ}$; Zink and Bairlein 1995, see also Bolshakov et al. 2001).

However, when birds recovered during a later winter are included, the spread of recovery sites from the place of ringing is much larger $\left(188^{\circ}\right.$ compared to $110^{\circ}$ in the Chaffinch as found in the recoveries from the Courish Spit, Payevsky 1998, see also Zink and Bairlein 1995). Such a large spread of recoveries in different winters ranging from Ireland and Portugal to the Caucasus and the Caspian Sea has been observed in winter-ringed birds across Europe (Bairlein et al. 2014; Cepák et al. 2008; Csörgö et al. 2009; Jenni 1982; Spina and Volponi 2008; Wernham et al. 2002; Zink and Bairlein 1995), although birds ringed in Norway have not been found east of Italy (Bakken et al. 2006).

Spring migration is basically in the reverse direction of autumn migration. It appears, however, that birds wintering 
in Switzerland can reach breeding sites between Scandinavia in the west to European Russia and western Siberia in the east (basin of the river $\mathrm{Ob}$; recovery of a Swiss bird ringed in December found at $63^{\circ} \mathrm{N} / 66^{\circ} \mathrm{E}$ in the following May; Jenni 1982), a spread of about $50^{\circ}$ and an $\mathrm{E}-\mathrm{W}$ distance in the core breeding range of about $2000 \mathrm{~km}$ (see also Bairlein et al. 2014; Zink and Bairlein 1995). It is also known that breeding site fidelity is extremely low, so that the Brambling was called a nomadic species (Hogstad 1985; Lindström 1987; Mikkonen 1983). In Fennoscandia, breeding site dispersal has been observed over $580 \mathrm{~km}$ (Fransson and Hall-Karlsson 2008; Lindström 1987) and might cover even longer distances, given the very low recovery probability in boreal forests.

Ringing recoveries could not demonstrate a difference in breeding range origin of Bramblings which participate in mass concentrations versus Bramblings in normal winters in Switzerland. However, this may be due to a lack of conclusive recoveries of ringed birds.

This study confirmed that Bramblings from mass concentrations are more spread across Europe and slightly further south in another winter than birds from normal winters. The question is how they reach these widely spread wintering areas. Up to now, variation in the direction of autumn migration was suspected as the cause, i.e., birds from western Siberia might vary their direction by only $30^{\circ}$ and reach either central Europe or the Caucasus, but it is unclear what the proportion of Siberian Bramblings involved is and how Bramblings would know whether to head for central Europe or the Caucasus for a beech mast. However, with the observed spread of directions of spring migration Bramblings can also reach very different breeding areas. Therefore, it remains unclear whether the widely dispersed sites in different winters are reached with a variation in autumn or spring migration direction or both. The quite constant and concentrated same-season autumn migration directions in Europe suggest that breeding dispersal (and hence variation in spring migration direction) may play a larger role than hitherto acknowledged.

Autumn ringed individuals from Switzerland showed that Bramblings wintered further south when not participating in mass concentrations. Furthermore, autumn migration through southern Switzerland is reduced in years of a mass concentration in central Europe (but not western or eastern Europe) (Jenni 1985; Korner-Nievergelt et al. 2007) and mass concentrations occur wherever Bramblings first encounter a mass fructification of the beech on their SW autumn migration direction (Jenni 1987).

This supports the pattern that Bramblings, as other migrants, leave the breeding area on a broad front in a southwesterly direction (perhaps channelled to some extent by the sea and mountain ranges) which is not more variable than in other migrants. If a beech mast occurs on their way, many of them stop and later form mass concentrations. Beech masts typically occur in central Europe (i.e., between south Sweden and the Alps) synchronized over areas of several hundreds of kilometres (Ascoli et al. 2017; Nussbaumer et al. 2016; Vacchiano et al. 2017). If there is no beech mast, or the beech seeds are covered by snow, Bramblings winter on average further south (e.g., many in northern Italy, central and southern France), but also in central Europe, and in rare cases reach North Africa and the oases of the northern Sahara (Cramp and Perrins 1994; Spina and Volponi 2008; Zink and Bairlein 1995). In spring, Bramblings typically reach breeding areas different from the previous one.

The question is whether this pattern of parallel SW-oriented Brambling migration is sufficient that up to 10 million birds are halted by a beech mast. The European breeding population is estimated at 15-24 million pairs (hence 30-48 million adults; BirdLife International 2015) which are spread over a core breeding area of $2000 \mathrm{~km}$ in $\mathrm{E}-\mathrm{W}$ direction (Norway-Ural). Assuming that these breeding birds migrate homogenously in parallel in SW direction, 1.5-2.4 million adults would cross a line of $100 \mathrm{~km}$. Assuming a very large mass concentration with two roosts of 5 million birds each (Jenni and Neuschulz 1985) and 50\% adult males, the catchment line of a parallel SW autumn migration would need to be $400-660 \mathrm{~km}$ wide to halt the required 5 million adult males. Beech mast areas are several hundred kilometres wide (Ascoli et al. 2017; Nussbaumer et al. 2016; Vacchiano et al. 2017), and hence a simple, albeit complete halt of a strictly parallel SW autumn migration could indeed produce large mass concentrations. However, this rough estimate does not account for the (unknown) mortality of adults after breeding, and does not verify whether the (variable) breeding success would make up the ca. $30 \%$ juveniles in mass roosts.

On the other hand, the following arguments, not considered in this very rough estimate, would lead more Bramblings to European beech mast areas: The large breeding population in western Siberia probably also migrates partly to European wintering areas (as suggested by indirect recoveries and the smaller extent of post-juvenile moult of birds participating in mass concentrations). Bramblings, as beech seed specialists, might well converge their migration directions to the centre of the distribution of beech [Fagus sylvatica, $F$. (sylvatica) moesiaca, and $F$. orientalis] which ranges from the Pyrenees to the Carpathians with some smaller areas in northern Asia Minor and the Caucasus. Bramblings probably search for beech mast at the beginning of the winter. Such a behaviour is indicated by the fact that mass roosts build up only in December (second half of November at the earliest), well after the end of autumn migration (Jenni and Neuschulz 1985), and within-winter recoveries up to several hundred kilometres confirm a substantial range of withinwinter movements (Bønløkke et al. 2006; Jenni 1982; Spina and Volponi 2008; Wernham et al. 2002. 


\section{Differential migration by age and sex groups}

The second aim was to shed light on the differences between age and sex groups in their spatio-temporal migration and participation in mass concentrations.

During autumn migration in Switzerland, proportionally more adults of both sexes pass through with progressing season which has also been observed at the Courish Spit (Payevsky 2009). This indicates a slight difference in timing of migration between the age classes. Reasons may be that adults perform a complete moult of about 60 days (Holmberg 1992), while juveniles perform a partial moult of probably shorter duration.

Across Europe, the proportion of juvenile males decreases towards south (i.e., with increasing migration distance) in autumn migrants and in wintering birds, while adult females show the opposite pattern. This agrees with the finding from recoveries that juvenile males winter furthest north and adult females furthest south among the four age-sexgroups (Fransson and Hall-Karlsson 2008; Payevsky 1998, 2009, 2020; Valkama et al. 2014). The change in proportions with latitude is smaller for adult males and juvenile females which, according to recoveries, occupy on average intermediate wintering sites along the north-south-axis (Fransson and Hall-Karlsson 2008; Payevsky 2009, 2020). The findings derived from winter positions of recoveries and from the proportions of age-sex-groups are not directly comparable, because proportions are contingent on each other and independent of the actual number of birds involved, while mean recovery positions are not, but depend on geographical recovery probability. In summary, differential migration and wintering grounds according to age and sex groups could be confirmed for years without a mass concentration.

Several hypotheses have been put forward to explain differential migration and wintering according to age and sex in birds which probably act in combination rather than singly (Cristol et al. 1999; Ketterson and Nolan 1983; Newton 2008; Payevsky 2020). The three hypotheses usually put forward to explain age and sex differentiation in migration (see Cristol et al. 1999; Ketterson and Nolan 1983; Payevsky 2020) may explain why female Bramblings generally winter further south than males, a pattern observed in many other size-dimorphic species (Newton 2008). The 'body size hypothesis' states that the larger males can winter in colder and more unpredictable regions with shorter day length, because they tolerate cold better and can survive longer with a given amount of energy stores; whether the relatively small size difference between male and female Bramblings is decisive remains to be shown. The 'social dominance hypothesis' predicts that the (presumably) dominant male Bramblings may displace females to poorer and/or far off wintering areas through competition; this is probably more likely when food becomes scarce, e.g., with snow, and hence may act in more northern wintering areas. The 'arrival time hypothesis' states that wintering closer to the breeding area supports an earlier arrival and securing of breeding territories which is more important for males than females (Morbey and Ydenberg 2001); indeed, male Bramblings leave the winter quarters earlier than females (Cramp and Perrins 1994), but this explanation hinges on a relationship between migration distance and arrival time. Another reason for females wintering at different places than males is that females may prefer different foods, because they can handle large seeds less expeditiously than males (see below).

In Bramblings, however, adults winter further south than juveniles within each sex, which among passerines has been found only in Chaffinch, Dark-eyed Junco Junco hyemalis, and Fieldfare Turdus pilaris (Ketterson and Nolan 1982, 1983; Milwright 1994; Newton 2008; Payevsky 1998, 2020), all mainly ground-feeders in winter. For ground-feeders in temperate areas, there is a high risk that sudden snowfalls cover their food. Wintering further south (or southwest in Europe) lowers the risk of snow cover, hence risk of starvation or the risks involved when searching for snow-free areas, a strategy which adults apparently pursue. The question then is why juveniles do not also winter further south and incur a higher risk of starvation due to snow cover. Apparently, there are some costs which increase with migration distance and affect juveniles more than adults. These may be direct travel costs and risks during migration (e.g., increased mortality), or the indirect cost of arriving later in the breeding area than the adults. Because the distribution of food in winters without beech mast across Europe is unknown, it is unclear whether the probably subdominant juveniles are kept away by the probably dominant adults from preferred feeding grounds.

\section{Differential participation in mass concentrations by age and sex groups}

In Bramblings, further complexity to differential wintering quarters is added through a differential participation in mass concentrations. Mass concentrations in Switzerland were composed of significantly more adults, especially adult males, and fewer juveniles, particularly juvenile females, while the sex-age composition outside mass concentrations was similar to normal winters. This was also evident when looking at the few data from abroad.

Prior to a mass concentration, the number of birds on autumn migration and the proportion of males is reduced (Jenni 1985, this study). Males are apparently more held up by beech mast than females.

Within a mass concentration, there can be further differentiations according to age-sex groups. First, the three samples from the Kernwald roost contained a higher proportion of adult males and a lower proportion of adult females 
than the two samples from the concurrent Röserental roost, for which I have no reasonable explanation. Second, there may be changes in the age-sex composition along the winter. In a mass roost in northern Spain, the proportion of adults was highest in mid-winter (Arizaga et al. 2012); whether this was related to snowfall further north remains unknown. In spring, males apparently depart earlier than females from mass roosts (Mühlethaler 1952; Zinnenlauf 1967) which agrees with an earlier arrival on the breeding grounds (Mikkonen 1981). Third, there is a differentiation according to age and sex within the roost where adult males occupy the central and best roosting sites (Jenni 1993).

Beech mast offers superabundant and easily acquired food. The daily food requirements of about 40 beech seeds per day (Kjellén and Lindström 1993, own estimations) are taken up within $1.5 \mathrm{~h}$ at most when in a beech mast wood (Schäpper 1986). Therefore, the question is why females and juveniles do not particularly take advantage of this food surplus.

The risk, however, that snow prevents access to beech mast is high. In about $50 \%$ of winters, Bramblings had to give up beech mast areas due to snowfall (Jenni 1987). Then suddenly, a large number of birds have to rely on very scarce alternative food (e.g., from feeders) or have to find snow-free areas with less food available at some considerable distance (e.g., Jenni and Neuschulz 1985). In this case, adult males are probably at an advantage. First, they are presumably dominant over females and juveniles. Second, they accumulate larger energy stores than females and juvenile males when temperatures drop below freezing. These energy stores are larger the bigger the roost is, and become the largest found among small passerines in winter. They allow survival of several days without food intake (Jenni and Jenni-Eiermann 1987). Third, the risk of predation is probably lower for adult males, because they can stay in the centre of flocks and roosts which in turn allows them to carry larger energy reserves (Jenni 1993; Jenni and JenniEiermann 1987). Fourth, male Bramblings are probably better adapted to consume beech seeds than females. Males husk and eat hard, dry beech seeds almost twice as fast as females (50.6 s versus $93.4 \mathrm{~s}$ ) and soaked beech seeds $33 \%$ faster (24.8 s versus $33.0 \mathrm{~s}$; Schäpper 1986). This may be due to a difference in bill size, which however is very small (Table S4) or to the fact that females usually pick up all crumbs, while males more readily leave remains of a beech seed (Schäpper 1986).

\section{Conclusions}

This study suggests that mass concentrations of Bramblings are mainly composed of birds migrating in their normal SW direction, possibly with a higher fraction of eastern birds, which are held up by beech mast. This study also showed that the spatio-temporal migration and wintering pattern of the Brambling is quite complex. It varies between years depending on food availability, and differs between age and sex groups depending on latitude and mass concentrations. Hence, the optima of wintering sites differ between age and sex groups depending on migration distance and the occurrence of beech mast.

It seems that adults and females benefit from wintering further south where snow is less likely to cover food of this ground-feeding finch. On the other hand, the costs of migration are probably substantial in terms of direct costs or indirectly in terms of reaching the breeding grounds, so that juvenile males prefer to winter closer to the breeding area.

Despite superabundant and easily available food in beech mast areas, females and juveniles do not readily benefit from it. Feeding in large flocks in beech mast areas incurs the substantial risk of being cut off from this food by snowfall. Adult males are apparently best adapted to this risk, and hence predominate in mass concentrations.

In the non-breeding season, the Brambling is specialised on large seeds, particularly beech seeds (Ziswiler 1965), which by late autumn are all on the ground. Because there are no abundant large seeds available in the breeding area, or are snow-covered, the Brambling probably has to leave its breeding range entirely. In the wintering area, snowfall covering this food is the main risk for this specialised ground feeder in winter and hence can explain many aspects of the differential migration and wintering according to age and sex.

Several questions remain of which I would like to mention three. First, despite the huge variation in winter density and distant winter quarters, winter site fidelity over several winters has been observed repeatedly in all age and sex classes (Cepák et al. 2008; Haar 1975; Hilprecht 1965; Jenni 1982; Schlenker 1976; Verheyen 1954). It is also suspected that Bramblings which change the winter site during one winter may come back to the first in a later winter (Schlenker 1976). Therefore, the question is which proportion of the population shows winter site fidelity and whether it depends on age or sex.

Second, the cues and the behaviour which leads Bramblings to congregate within 1 or 2 months, probably over hundreds of kilometres, into groups of millions of birds are still unknown. The same question may also be asked for the breeding assemblages.

Third, although there is no, or only sparse (see Svensson 2021), indication that breeding densities and success are related to numbers or mass concentrations in the following winter (unlike in typical irruptive species, e.g., tits), it would be interesting to see whether the varying densities and breeding success in the breeding area affect the numbers and age and sex composition in winter. 
Supplementary Information The online version contains supplementary material available at https://doi.org/10.1007/s10336-021-01916-7.

Acknowledgements I thank I. C. J. Galbraith for allowing us to measure the birds in the collection of the Natural History Museum, Tring UK, and the following museums and their curators for sending Brambling specimens to Switzerland more than 35 years ago: Natural History Museum of Denmark, Copenhagen (Jon Fieldså), The Arctic University Museum of Norway, Tromsø (Hans-Petter Mannvik and Wim Vader), Natural History Museum, University of Oslo (Tore Slagsvold), Zoologisches Forschungsmuseum Alexander Koenig, Bonn (Renate van den Elzen), Swedish Museum of Natural History, Stockholm (Bo Fernholm), and Finnish Museum of Natural History, Helsinki (Ann Forstén). I thank Raffael Winkler, Natural History Museum Basel for managing these specimen exchanges. I thank Susanne Jenni-Eiermann for help with measuring the large collection of the Natural History Museum at Tring). Special thanks go to the many Swiss volunteer ringers (mentioned in Materials and Methods) who took the initiative to ring Bramblings during normal winters and when the unpredictable mass concentrations suddenly occurred, an undertaking hardly possible under current legislation. I thank Jan von Rönn for providing ringing and recovery data of Bramblings from the databases of the Swiss Ornithological Institute, and the following ringing stations and persons for generously sharing their data: Falsterbo Bird Observatory, Ottenby Bird Observatory, Åke Lindström (data from the Lund area), Biological station Rybachy (Arseny Tsvey and the team), Denis Kitel (data from Belarus), Ulmethöchi ringing group, Col de Jaman (Lionel Maumary and Laurent Vallotton), and Greifswalder Oie (Ringing scheme Hiddensee and Jan von Rönn). Finally, I thank Pius Korner for preparing most of the graphs, Sophie Marti for preparing the recovery maps, and Ian Newton, Gilberto Pasinelli and Jan von Rönn for commenting on the manuscript.

Funding Open Access funding provided by Schweizerische Vogelwarte.

Availability of data and material The data are available in a repository. The link will be available on 3 August 2021: "Biometry data to reveal geographic variation in Bramblings Fringilla montifringilla" at https:// doi.org/10.5281/zenodo.5077897 and "Data on the sex and age composition of Bramblings Fringilla montifringilla during autumn migration and winter in Europe" at https://doi.org/10.5281/zenodo.5077926.

Open Access This article is licensed under a Creative Commons Attribution 4.0 International License, which permits use, sharing, adaptation, distribution and reproduction in any medium or format, as long as you give appropriate credit to the original author(s) and the source, provide a link to the Creative Commons licence, and indicate if changes were made. The images or other third party material in this article are included in the article's Creative Commons licence, unless indicated otherwise in a credit line to the material. If material is not included in the article's Creative Commons licence and your intended use is not permitted by statutory regulation or exceeds the permitted use, you will need to obtain permission directly from the copyright holder. To view a copy of this licence, visit http://creativecommons.org/licenses/by/4.0/.

\section{References}

Ålbu T (1983) Post-juvenile growth in passerines. Fauna Norvegica, Series C Cinclus 6:53-56

Arizaga J, Zuberogoitia I, Zabala J, Crespo A, Iraeta A, Belamendia G (2012) Seasonal patterns of age and sex ratios, morphology and body mass of Bramblings Fringilla montifringilla at a large winter roost in southern Europe. Ringing Migr 27:1-6. https://doi.org/ 10.1080/03078698.2012.686707

Ascoli D, Vacchiano G, Turco M, Conedera M, Drobyshev I, Maringer J, Motta R, Hacket-Pain A (2017) Inter-annual and decadal changes in teleconnections drive continental-scale synchronization of tree reproduction. Nature Comm 8:2205. https://doi.org/ 10.1038/s41467-017-02348-9

Bairlein F, Dierschke J, Dierschke V, Salewski V, Geiter O, Hüppop K, Köppen U, Fiedler W (2014) Atlas des Vogelzuges. Ringfunde deutscher Brut- und Gastvögel. Aula, Wiebelsheim

Bakken V, Runde O, Tjørve E (2006) Norsk Ringmerkingsatlas, Vol. 2. Stavanger Museum, Stavanger

BirdLife International (2015) European Red List of Birds. http://dataz one.birdlife.org/info/euroredlist

Bønløkke J, Madsen JJ, Thorup K, Pedersen KT, Bjerrum M, Rahbek C (2006) Dansk Trækfugleatlas. Rhodos, Humlebæk

Bolshakov CV, Shapoval AP, Zelenova NP (2001) Results of bird ringing by the Biological Station "Rybachy" on the Courish Spit: long-distance recoveries of birds ringed in 1956-1997. Part 3. Fringilla coelebs, Fringilla montifringilla. Avian Ecol Behav Suppl 3:1-130

Browne SJ, Mead CJ (2003) Age and sex composition, biometrics, site fidelity and origin of Brambling Fringilla montifringilla wintering in Norfolk, England. Ringing Migr 21:145-153. https://doi.org/ 10.1080/03078698.2003.9674283

Cepák J, Klvaňa P, Škopek J, Schröpfer L, Jelínek M, Hořák D, Formánek J, Zárybnický J (2008) Atlas migrace ptáků České republiky a Slovenska. Aventinum, Praha

Cramp S, Perrins CM (1994) Handbook of the birds of Europe, the Middle East and North Africa. The birds of the Western Palearctic, vol 8. Oxford University Press, Oxford

Cristol DA, Baker MB, Carbone C (1999) Differential migration revisited. Latitudinal segregation by age and sex class. Current Ornithol 15:33-88

Csörgö T, Karcza Z, Halmos G, Magyar G, Gyurácz J, Szép T, Bankovics A, Schmidt A, Schmidt E (2009) Magyar madárvonulási atlasz. Kossuth Kiadó, Budapest

Enemar A, Sjörstrand B, Andersson G, von Proschwitz T (2004) 37-year dynamics of a subalpine passerine bird community, with special emphasis on the influence of environmental temperature and Epirrita autumnata cycles. Ornis Svecica 14:63-106

Fransson T, Hall-Karlsson S (2008) Swedish Bird Ringing Atlas, Vol. 3. Naturhistoriska Riksmuseet \& Sveriges Ornitologiska Förening, Stockholm

Glutz von Blotzheim UN, Bauer KM (1997) Handbuch der Vögel Mitteleuropas, vol 14. Aula-Verlag, Wiesbaden

Haar H (1975) Der Bergfink (Fringilla montifringilla) als Durchzügler und Wintergast in der Oststeiermark (Aves). Mitt Abt Zool Landesmus Joanneum 4:105-114

Hilprecht A (1965) Ringfunde des Bergfinken (Fringilla montifringilla). Auspicium 2:91-118

Hogstad O (1985) Annual variation in mean body size of a Brambling Fringilla montifringilla population. Ornis Fennica 62:13-18

Hogstad O (2000) Fluctuation of a breeding population of Brambling Fringilla montifringilla during 33 years in a subalpine birch forest. Ornis Fennica 77:97-103

Hogstad O (2005) Numerical and functional responses of breeding passerine species to mass occurrence of geometrid caterpillars in a subalpine birch forest: a 30-year study. Ibis 147:77-91

Holmberg T (1992) The primary moult of the Brambling Fringilla montifringilla evaluated by four different methods. Ornis Svecica 2:139-156

Jenni L (1982) Schweizerische Ringfunde von Bergfinken Fringilla montifringilla: Ein Beitrag zum Problem der Masseneinflüge. Ornithol Beob 79:265-272 
Jenni L (1985) Der Herbstzug des Bergfinken Fringilla montifringilla in der Schweiz und Beziehungen zu Masseneinflügen in Mitteleuropa. Vogelwarte 33:53-63

Jenni L (1987) Mass concentrations of Bramblings Fringilla montifringilla in Europe 1900-1983: Their dependence upon beech mast and the effect of snow cover. Ornis Scand 18:84-94

Jenni L (1993) Structure of a Brambling Fringilla montifringilla roost according to sex, age and body mass. Ibis 135:85-90

Jenni L, Jenni-Eiermann S (1987) Body weight and energy reserves of Bramblings in winter. Ardea 75:271-284

Jenni L, Neuschulz F (1985) Die Masseneinflüge von Bergfinken Fringilla montifringilla 1977/78 und 1982/83 in der Schweiz: Abhängigkeit von der Schneedecke und vom Nahrungsangebot. Ornithol Beob 82:85-106

Jenni L, Winkler R (1989) The feather-length of small passerines: a measurement for wing-length in live birds and museum skins. Bird Study 36:1-15

Jenni L, Winkler R (2020a) Moult and ageing of European Passerines, 2nd edn. Christopher Helm, London

Jenni L, Winkler R (2020b) The biology of moult in birds. Christopher Helm, London

Kestenholz M, Schaffner W (1993) Masseneinflüge von Bergfinken Fringilla montifringilla ins Fricktal. Ornithol Beob 90:297-299

Ketterson ED, Nolan VJ (1982) The role of migration and winter mortality in the life history of a temperate-zone migrant, the Darkeyed Junco, as determined from demographic analyses of winter populations. Auk 99:243-259

Ketterson ED, Nolan VJ (1983) The evolution of differential bird migration. Current Ornithol 1:357-402

Khil L, Samwald O, Tiefenbach A, Tiefenbach M, Pacher H (2011) Der Massenschlafplatz von Bergfinken Fringilla montifringilla in Österreich im Winter 2008/2009. Limicola 25:81-100

Kiat Y, Davaasuren B, Erdenechimeg T, Troupin D, Sapir N (2021) Large-scale longitudinal climate gradient across the Palearctic region affects passerine feather moult extent. Ecography 44:124133. https://doi.org/10.1111/ecog.05287

Kjellén N, Lindström A (1993) Bergfinkens övervintringsstrategier samt några iakttagelser från en skånsk sovplats i januari-februari 1993. Anser 32:187-199

Korner-Nievergelt F, Korner-Nievergelt P, Baader E, Fischer L, Schaffner W, Kestenholz M (2007) Herbstlicher Tagzug auf der Beringungsstation Ulmethöchi im Jura: Veränderungen in den Fangzahlen über 40 Jahre (1966-2005). Ornithol Beob 104:3-32

Lindström $\AA$ (1987) Breeding nomadism and site tenacity in the Brambling Fringilla montifringilla. Ornis Fennica 64:50-56

Lindström A, Enemar A, Andersson G, von Proschwitz T, Nyholm NEI (2005) Density-dependent reproductive output in relation to a drastically varying food supply: getting the density measure right. Oikos 110:155-163

Mikkonen AV (1981) The time of spring migration of the Chaffinch Fringilla coelebs and the Brambling $F$. montifringilla in northern Finland. Ornis Scand 12:194-206

Mikkonen AV (1983) Breeding site tenacity of the Chaffinch Fringilla coelebs and the Brambling $F$. montifringilla in northern Finland. Ornis Scand 14:36-47

Milwright RDP (1994) Fielfare Turdus pilaris ringing recoveries during autumn, winter and spring, analysed in relation to river basins and watersheds in Europe and the Near East. Ringing Migr 15:129-189

Morbey YE, Ydenberg RC (2001) Protrandrous arrival timing to breeding areas: a review. Ecol Lett 4:663-673

Mühlethaler F (1952) Beobachtungen am Bergfinken-Schlafplatz bei Thun 1950/51. Ornithol Beob 49:173-181

Newton I (2008) The migration ecology of birds. Academic Press, London
Nussbaumer A, Waldner P, Etzold S, Gessler A, Benham S, Thomsen IM, Jørgensen BB, Timmermann V, Verstraeten A, Sioen G, Rautio P, Ukonmaanaho L, Skudnik M, Apuhtin V, Braun S, Wauer A (2016) Patterns of mast fruiting of common beech, sessile and common oak, Norway spruce and Scots pine in Central and Northern Europe. Forest Ecol Manag 363:237-251. https://doi.org/10. 1016/j.foreco.2015.12.033

Payevsky VA (1998) Bird trapping and ringing as an inexhaustible source of most valuable data for demographic investigations (with special reference to the work of the Biological Station Rybachy). Avian Ecol Behav 1:76-86

Payevsky VA (2009) Songbird demography. Pensoft Publ, Sofia, Moscow

Payevsky VA (2020) Differential migration of birds: Diversity and inconsistency. Biology Bull 47:724-734

Robson D (1996) Influencia de la temperatura en la masa corporal del Pinzon Real. Ardeola 43:139-144

Schäpper R (1986) Zum Verhalten überwinternder Bergfinken Fringilla montifringilla beim Nahrungserwerb in einem Buchenmastgebiet. Ornithol Beob 83:142-145

Schierer A (1957) Geschlechts- und Altersverhältnis der Nordfinken. Vögel Heimat 27:68

Schlenker R (1976) Winterplatztreue beim Bergfinken. Vogelwarte 28:313-314

Sokal RR, Rohlf FJ (1995) Biometry, 3rd edn. W.H. Freeman \& Co, New York

Spina F, Volponi S (2008) Atlante della migrazione degli uccelli in Italia, Vol. 2. Ministero dell' ambiente e della tutela del territorio e del mare, Istituto Superiore per la Protezione e la Ricerca Ambientale (ISPRA), Roma

Svensson T (2021) A review of mass concentrations of Bramblings Fringilla montifringilla: implications for assessment of large numbers of birds. Ornis Svecica 31:44-67

Vacchiano G, Hacket-Pain A, Turco M, Motta R, Maringer J, Conedera M, Drobyshev I, Ascoli D (2017) Spatial patterns and broadscale weather cues of beech mast seeding in Europe. New Phytol 215:595-608. https://doi.org/10.1111/nph.14600

Valkama J, Saurola P, Lehikoinen A, Lehikoinen E, Piha M, Sola P, Velmala W (2014) The Finnish Bird Ringing Atlas, Vol. II. Finnish Museum of Natural History and Ministry of Environment, Helsinki

Verheyen R (1954) Les pinsons du Nord en Belgique. Gerfaut 44:324-342

Wernham CV, Toms MP, Marchant JH, Clark JA, Siriwardena GM, Baillie SR (2002) Migration Atlas: Movements of the Birds of Britain and Ireland. T. \& A. D. Poyser, London

Widemo U (1977) Bergfink Fringilla montifringilla Jan. - Apr. 1977. Sex and age distribution, winglength and change of weight. Fåglar i Sörmland 10:6-81

Zink G, Bairlein F (1995) Der Zug europäischer Singvögel. Ein Atlas der Wiederfunde beringter Vögel. Lieferung V. Aula, Wiesbaden

Zinnenlauf B (1967) Der Masseneinfall von Bergfinken im Winter 1965/66 in der Schweiz. Ornithol Beob 64:113-118

Ziswiler V (1965) Zur Kenntnis des Samenöffnens und der Struktur des hörnernen Gaumens bei körnerfressenden Oscines. J Ornithol 106: $1-48$

Publisher's Note Springer Nature remains neutral with regard to jurisdictional claims in published maps and institutional affiliations. 